\title{
Financial Asset Ownership: The Case of Chinese and Indian Immigrants to the United States
}

\section{Lisa A Keister*}

Department of Sociology, Duke University, USA

\begin{abstract}
Financial asset ownership is important for a large number of scholarly and practical reasons including for understanding saving propensities, risk taking, personal financial strategies, inequality, the flow of funds across national borders, and organizational marketing strategies. Yet we know little about group differences in approaches to owning various financial instruments. Chinese and Indian immigrants to the United States are large, growing, and diverse groups who are rapidly beginning to comprise a large portion of the U.S. population and whose unique financial asset ownership patterns offer insight into the factors that contribute to cross-group differences in this important behavior. The article studies how members of these two important groups own particular assets. Use data from the U.S. Census Bureau's Survey of Income and Program Participation (SIPP) and find that, Chinese and Indian immigrants do, indeed, exhibit unique asset ownership patterns when they are compared to native whites, African Americans, and other immigrants. Their ownership of stocks and mutual funds, interest-earning bank accounts, retirement accounts and whole life insurance. My findings demonstrate that age, tenure in the United States, education, and family traits are important meditating in the relationship between country of birth and financial asset ownership.
\end{abstract}

Keywords: Financial asset ownership; Chinese immigrants; Indian immigrants; Wealth; Inequality

\section{Introduction}

Understanding trends in the ownership of various financial assets is critical for a large number of scholarly and practical reasons. Knowing who owns assets such as stocks, mutual funds, bank accounts, and retirement accounts provides information about why there are large variations in saving propensities and risk taking across households, and how these affect differences in well-being across nations [1,2]. Financial asset ownership also provides important information about patterns of inequality; wealth inequality is particularly extreme in most developed countries, and financial asset ownership is essential to understanding cross-household variations in net worth $[3,4]$. Financial asset ownership is critical to personal finance and investing: these relatively liquid assets typically account for the majority of the portfolios of high net worth individuals and can be used effectively to create more wealth through effective investing. For the less wealthy, financial assets provide a buffer against financial emergencies that can otherwise lead to enormous personal loss. Patterns in financial asset ownership also provide information about global flows of funds and cross-national investing because, unlike the ownership real assets (e.g., housing, real estate), financial asset ownership can occur outside the owner's country of residence $[5,6]$. Moreover, organizations such as banks and investment firms are concerned about the types of people who own financial assets because it can allow them to target marketing, customer service, and other management functions more efficiently [7]. Despite the importance of financial asset ownership, we know very little about trends across groups in this behavior.

Chinese and Indian immigrants to the United States are large, growing, and diverse groups who are rapidly beginning to comprise a large portion of the U.S. population and whose unique financial asset ownership patterns offer insight into the factors that contribute to cross-group differences in this important behavior. Since the U.S. implemented immigration reforms in 1965, Asians have grown from $1 \%$ to $6 \%$ of the country's population. In 2009, Asian Americans surpassed Latinos as the fastest growing immigrant group [8]. The growth in the Asian population has increased recently, and this change was driven largely by Chinese and Indian immigrants [9]. In 2005, Chinese represented 5\% and Indians $4 \%$ of immigrants to the U.S Since 2008, Chinese have grown to comprise $9 \%$ and Indians $8 \%$ of all immigrants arriving in the U.S. [9]. Chinese and Indian immigrants have attracted research attention in part because their average incomes, education levels, and occupational accomplishments tend to equal or surpass those of native whites $[8,10]$. There is also preliminary evidence that suggests Chinese and Indian immigrants to the U.S. have high levels of overall wealth fueled partly by uniquely high propensities to own financial assets [11]. Previous research on immigrant attainment focuses are large numbers of immigrant groups and tends to make general claims about the relative ranking of these groups. Moreover, previous studies of immigrant wealth are rare, and none has provided an in-depth exploration of the financial assets of Chinese and Indian Americans.

This article fills this gap by exploring how Chinese and Indian immigrants to the United States own financial assets; compare their asset ownership to that of native whites and blacks and to other immigrants in order to identify how they contrast with multiple other groups. The focus is on the ownership of all financial assets, as well as the ownership of stocks and mutual funds, interest-earning bank accounts, Individual Retirement and Keogh accounts, and whole life insurance (i.e., life insurance with some investment value). This study also examines how various other demographic traits (e.g., age, tenure in the United States, education, and family traits) are associated with

*Corresponding author: Lisa A Keister, Professor, Department of Sociology, 268 Sociology/Psychology Building, N 27708, Duke University, USA, Tel: (919) 660-5624; Fax: 919-660-5623; E-mail: Ikeister@soc.duke.edu

Received August 21, 2015; Accepted September 10, 2015; Published September 17,2015

Citation: Keister LA (2015) Financial Asset Ownership:The Case of Chinese and Indian Immigrants to the United States. Bus Eco J 6: 184 doi:10.4172/2151 6219.1000184

Copyright: ( 2015 Keister LA. This is an open-access article distributed under the terms of the Creative Commons Attribution License, which permits unrestricted use, distribution, and reproduction in any medium, provided the original author and source are credited. 
financial asset ownership for these groups. It uses data from the United States Census Bureau's Survey of Income and Program Participation (SIPP) to study these questions. SIPP data are widely regarded as among the best estimates of household-level wealth ownership that also includes information on ethnicity and country of birth. My findings show that Chinese and Indian immigrants to the U.S. are, indeed, unique in their ownership of financial assets. These groups are highly likely to own all types of financial assets and to hold large values in their accounts. Importantly, both the likelihood and amount owned increase with age, tenure in the U.S., and education. However, there are important differences across Chinese immigrants (i.e. between those from Mainland China and those from Hong Kong/Taiwan) and between Chinese and Indian immigrants.

\section{Factors Influencing Financial Asset Ownership}

\section{Tenure in the United States}

The association between tenure in the host country and attainment is a source of much of the controversy underlying in the immigration literature, and unique tenure-wealth patterns for Chinese and Indian immigrants to the U.S. have the potential to shed some light on how tenure functions. The number of years an immigrant has spent in the host country is an indicator of the amount of time the person has had to adapt to conditions in the new context; this suggests that tenure should be strongly and positively associated with attainment. However, some groups do not attain expected levels of income, education, and wealth after time in the host country; and this has led to debate among immigration scholars $[12,13]$. The focus of this literature tends to be on the role that host country conditions the context of reception play in facilitating attainment, but tenure since immigration also provides critical information about the context under which both emigration and immigration occurred. Indeed, the context under which immigrants leave the home country the emigration context is arguably critical to their long-term well-being. Various waves of Chinese and Indian immigrants have migrated under varying and rapidly-changing social and economic conditions and have met with notably different contexts of reception that, together, are likely to be associated with their wealth ownership in the U.S.. It is useful to think of three broad waves that represent changes in both home and host country context. First, those who migrated more than 25 years ago (before 1989) left a context that was still developing, urbanizing, industrializing, and otherwise developing economically. Second, those who migrated between 11 and 25 years ago (1990-2004) would have emigrated from and to contexts that were markedly different from earlier waves of immigrants. A third wave, roughly since 2004, includes immigrants who have left relatively well-developed home countries and have arrived to equally well-developed Chinese and Indian communities in the U.S.

\section{Age}

Age is also likely to affect financial asset ownership as the life cycle hypothesis predicts [14]. This hypothesis suggests that people spread consumption and saving over their lifetimes. For accumulated wealth, this implies that people save until they retire and dissave after; that is, wealth should grow until retirement then decline. The empirical evidence, however, suggests that wealth continues to grow after retirement for most people because of uncertainty about the timing of death and the bequest motive. Understanding how life cycle processes operate differently for Chinese and Indian immigrants compare to native U.S. residents may be able to shed light on this debate.

\section{Education}

Education is an important predictor of wealth ownership, including financial asset ownership, because it reflects human capital as well as social advantages. For immigrants to the U.S., education is also important because certain visa categories (e.g., employment visas) are restricted to immigrants with high educational attainment and professional experience. Less skilled immigrants with low educational attainment are more likely to enter the U.S. through family reunification or diversity visas or without documentation. Social networks are particularly important for these immigrants, as they distribute information about border crossing, migration destinations, and work opportunities, thus making contact with members of these networks a crucial aspect of undocumented immigration.

\section{Differences between Chinese and Indian immigrants to the US}

Immigration research typically focuses on large numbers of immigrant groups and makes broad comparisons across groups. By contrast, focusing on a small number of groups (e.g., Chinese and Indian immigrants) allows more detailed and nuanced comparison and exploration of processes underlying immigrant behavior. There are likely to be both similarities and differences between Chinese and Indian immigrants that will both offer important information about financial asset ownership. Notably, there important differences in tenure, age, and education among members of these large groups that will affect their wealth ownership; much of these difference reflect historical differences in the immigration and selection process that began following the implementation of immigration reform in 1965. These differences also reflect more recent policy issues such as the groups that are targeted by U.S. visa regulations.

\section{Research Methods}

Analyses use data from the Survey of Income and Program Participation (SIPP). The SIPP is a multi-panel, nationallyrepresentative survey of U.S. households. Panels consisting of 14,000 to 36,700 households each are conducted every two to four years. The SIPP survey includes sizable Chinese and Indian immigrant samples as well as large samples of native whites, African Americans, and other comparison groups, making it appropriate for this study. Because waves of interviews are staggered within panels, the SIPP includes respondent data from 1984 to 2005 . The SIPP includes topical modules on migration history, including details on country of origin and time of arrival in the U.S. The SIPP contains detailed wealth information necessary for modeling accumulation patterns; it also includes employment history, education, public assistance receipt, family structure, and fertility.

My analyses include descriptive statistics that underscore the distinctiveness of cross-group patterns in financial asset ownership. And Ordinary Least Squares regression models of financial asset ownership as a function of country of birth and various other independent variables. My dependent variables in the regression models include total financial asset ownership and its components: stocks, mutual funds, interest-earning bank accounts, Individual Retirement Accounts and Keogh Accounts (two types of private retirement savings plans), and life insurance that has an investment component (often called whole life insurance). My results show variations in ownership of these assets by country of birth including respondents who were born in Mainland China, Hong Kong and Taiwan, India, and the United States (native U.S. residents). In my analyses, I respondents born in Hong Kong and Taiwan are combined because sample sizes are not large enough to separate these groups; moreover the geographic proximity and historic 
connections to mainland China (although they differ) are sufficiently similar to warrant combining these groups. For comparison, also included those born in other Asian countries, Mexico, Cuba, and other Latin American countries in my results, measured tenure in the United States as the number of years since the time the respondent relocated, age in years, and education in categories to capture the important breakpoints in the U.S. educational system (not a high school graduate, high school graduate, completed some college, has a college degree, has an advanced degree). Regression models, control for several other factors that are often associated with financial asset ownership including having a female-headed household, number of children, marital status, and region of residence in the U.S. controlled for survey year to adjust for unusual events (e.g., stock values) that would affect all respondents.

\section{Results}

The results first compared the demographic traits of Chinese and Indian immigrants to the U.S. with those of native whites, native blacks, and other immigrant groups, and show that Chinese and Indian immigrants in the SIPP sample were, indeed, unique in ways that are relevant to financial asset ownership. Chinese and Indian immigrants appeared to be slightly younger than native whites, although the difference is not statistically significant (Table 1). More importantly, Chinese and Indian immigrants in this sample were considerably more educated on average than any of the other groups included in the table. For example, relatively high proportions of Chinese and Indian immigrants had advanced degrees: $29 \%$ of Mainland Chinese, $31 \%$ of those born in Hong Kong or Taiwan, and $44 \%$ of Asian Indian immigrants had advanced degrees. By contrast, only $10 \%$ of native whites and only $5 \%$ of native blacks had advanced degrees. This large difference reflects both self-selection into immigration [15] and U.S. government preference for high-skilled immigrants that is reflected in immigration policies. Education levels for Chinese and Indian immigrants were higher than those of other immigrant groups, including immigrants from Mexico, Cuban, and other Latin American countries. This difference reflects the comparable difficulty immigrants from China and India have in immigrating to the U.S. illegally: it is more difficult for Asian immigrants to cross the U.S. border without legal documentation than for immigrants from countries that are more geographically proximate (Table 1 ).
Consistent with their high levels of education, Chinese and Indian immigrants in the SIPP sample were relatively more likely than other groups to be married. Whereas $66 \%$ of Mainland Chinese, $65 \%$ of those born in Hong Kong or Taiwan, and 79\% of Asian Indians were married, only $57 \%$ of native whites and $31 \%$ of native blacks were married. The same patterns are evident in the proportions of SIPP respondents with female-headed households: $20 \%$ of Mainland Chinese, $19 \%$ of those born in Hong Kong or Taiwan, and 7\% of Asian Indians had female-headed households. In contrast, $27 \%$ of native whites and $49 \%$ of native blacks had female-headed households. Finally, there were important differences between Chinese and Indian immigrants and other immigrant groups in their tenure in the U.S. Among immigrants from Mainland China, $43 \%$ had been in the U.S. fewer than 10 years, $30 \%$ had 11 to 25 years of tenure, and $23 \%$ had more than 25 years of tenure. Hong Kong and Taiwan immigrants had more moderate tenure lengths ( $43 \%$ had $11-25$ years), and Indian immigrants tended to be more recent (52\% had arrived within 20 years) (Table 2 ).

These differences were reflected in important differences in financial asset ownership: Chinese and Indian immigrants were more likely than other immigrants to own any financial assets and to own each of the particular classes of financial assets studied (Table 2). Moreover, for those who owned these financial assets, the median amount owned by Chinese and Indian immigrants was higher than for any other immigrant group. Indeed, Mainland Chinese immigrants had ownership rates and amounts that were comparable to those of native whites who have typically been considered the wealthiest racial or ethnic group in the U.S. $[4,16]$; even more noteworthy was that Hong Kong, Taiwan, and Indian immigrants owned amounts of financial assets that exceeded those of native whites. One extreme was Indian immigrants whose median total financial assets was $\$ 145,250$ compared to only $\$ 82,826$ for native whites (Table 3).

The results next show how median total financial assets owned varied by tenure in the U.S. Figures 1 and 2 demonstrate important patterns that very likely reflect differences in both the context under which people left their home countries and under which they entered the U.S. Figure 1 shows immigrant median total financial assets broken down by the amount of time the immigrant group has been in the U.S. (i.e., tenure). Figure 2 is a more conservative depiction of these patterns;

\begin{tabular}{|c|c|c|c|c|c|c|c|c|c|c|c|c|c|}
\hline Race/Nativity & $\mathbf{N}$ & Age & Less than HS & $\begin{array}{c}\text { HS } \\
\text { Graduate }\end{array}$ & $\begin{array}{l}\text { Some } \\
\text { College }\end{array}$ & College & $\begin{array}{c}\text { Advanced } \\
\text { Degree }\end{array}$ & $\begin{array}{c}\text { Female } \\
\text { Head }\end{array}$ & Children & Married & $\begin{array}{c}\text { US } \\
\text { Tenure } \\
0 \text { to } 10 \\
\text { yrs }\end{array}$ & $\begin{array}{c}\text { US } \\
\text { Tenure } \\
11 \text { to } 25 \\
\text { yrs }\end{array}$ & $\begin{array}{c}\text { US } \\
\text { Tenure } \\
\text { 25+ yrs }\end{array}$ \\
\hline $\begin{array}{l}\text { Mainland } \\
\text { Chinese }\end{array}$ & 327 & 49.95 & 0.21 & 0.19 & 0.07 & 0.25 & 0.29 & 0.20 & 0.58 & 0.66 & 0.43 & 0.30 & 0.23 \\
\hline HK-Taiwan & 150 & 45.14 & 0.06 & 0.16 & 0.10 & 0.37 & 0.31 & 0.19 & 0.92 & 0.65 & 0.27 & 0.43 & 0.29 \\
\hline Asian Indian & 330 & 40.43 & 0.03 & 0.07 & 0.07 & 0.39 & 0.44 & 0.07 & 0.89 & 0.79 & 0.52 & 0.29 & 0.16 \\
\hline Other Asian & 1,530 & 45.95 & 0.12 & 0.20 & 0.13 & 0.41 & 0.14 & 0.20 & 0.95 & 0.65 & 0.26 & 0.37 & 0.33 \\
\hline Native Asian & 1,283 & 47.45 & 0.09 & 0.22 & 0.20 & 0.40 & 0.09 & 0.28 & 0.74 & 0.52 & & & \\
\hline Mexican & 2,371 & 42.35 & 0.58 & 0.22 & 0.08 & 0.10 & 0.02 & 0.20 & 1.58 & 0.64 & 0.30 & 0.36 & 0.32 \\
\hline Cuban & 329 & 55.64 & 0.27 & 0.28 & 0.15 & 0.25 & 0.05 & 0.26 & 0.42 & 0.52 & 0.16 & 0.18 & 0.62 \\
\hline Other Latino & 1,968 & 47.14 & 0.22 & 0.27 & 0.14 & 0.27 & 0.09 & 0.31 & 0.92 & 0.52 & 0.28 & 0.32 & 0.37 \\
\hline Native Latino & 3,537 & 45.33 & 0.27 & 0.29 & 0.18 & 0.22 & 0.04 & 0.30 & 1.08 & 0.53 & & & \\
\hline $\begin{array}{l}\text { Other } \\
\text { Immigrants }\end{array}$ & 2,300 & 52.29 & 0.13 & 0.25 & 0.14 & 0.32 & 0.16 & 0.27 & 0.58 & 0.55 & 0.24 & 0.18 & 0.54 \\
\hline Native Black & 10,127 & 48.85 & 0.21 & 0.30 & 0.19 & 0.24 & 0.05 & 0.49 & 0.83 & 0.31 & & & \\
\hline Native White & 63,887 & 52.06 & 0.11 & 0.29 & 0.18 & 0.32 & 0.10 & 0.27 & 0.57 & 0.57 & & & \\
\hline
\end{tabular}


Citation: Keister LA (2015) Financial Asset Ownership:The Case of Chinese and Indian Immigrants to the United States. Bus Eco J 6: 184 doi:10.4172/2151-6219.1000184

Page 4 of 9

\begin{tabular}{|c|c|c|c|c|c|}
\hline Race/Nativity & Any Financial Assets & Stocks/Mutual Fund & Interest- earning Bank Account & IRA or Keogh & Life Insurance \\
\hline Mainland Chinese & 0.77 & 0.28 & 0.38 & 0.38 \\
\hline HK-Taiwan & 0.88 & 0.42 & 0.50 & 0.47 & 0.40 \\
\hline Asian Indian & 0.85 & 0.38 & 0.43 & 0.49 & 0.48 \\
\hline Other Asian & 0.74 & 0.21 & 0.31 & 0.39 & 0.48 \\
\hline Native Asian & 0.81 & 0.22 & 0.40 & 0.13 & 0.54 \\
\hline Mexican & 0.45 & 0.03 & 0.12 & 0.19 & 0.22 \\
\hline Cuban & 0.55 & 0.10 & 0.20 & 0.27 \\
\hline Other Latino & 0.65 & 0.13 & 0.25 & 0.28 \\
\hline Native Latino & 0.66 & 0.12 & 0.23 & 0.40 \\
\hline Other Immigrants & 0.81 & 0.27 & 0.40 & 0.24 \\
\hline Native Black & 0.70 & 0.10 & 0.20 & 0.47 \\
\hline Native White & 0.87 & 0.32 & 0.44 & 0.49 \\
\hline
\end{tabular}

Table 2: Financial assets by type - percentage of those with any, by country of birth

\begin{tabular}{|c|c|c|c|c|c|}
\hline Race/Nativity & Total Financial Assets & Stock/Mutual Fund & Interest-earning Bank Account & IRA or Keogh & Life Insurance \\
\hline Mainland Chinese & 66,404 & 17,915 & 9,351 & 18,180 & 133,590 \\
\hline HK-Taiwan & 94,728 & 30,300 & 11,363 & 26,524 & 133,590 \\
\hline Asian Indian & 145,250 & 30,300 & 12,630 & 28,054 & 156,300 \\
\hline Other Asian & 75,750 & 21,210 & 6,315 & 22,725 & 133,590 \\
\hline Native Asian & 53,860 & 32,688 & 3,978 & 21,210 & 75,750 \\
\hline Mexican & 10,104 & 12,120 & 1,603 & 28,054 & 73,152 \\
\hline Cuban & 42,420 & 6,060 & 3,340 & 26,524 & 75,783 \\
\hline Other Latino & 34,733 & 18,180 & 3,789 & 15,150 & 750 \\
\hline Native Latino & 35,401 & 18,635 & 2,526 & 33,397 & 67,750 \\
\hline Other Immigrants & 62,713 & 42,420 & 7,578 & 15,150 & 37,795 \\
\hline Native Black & 31,677 & 7,575 & 2,004 & 30,300 & 66,795 \\
\hline Native White & 82,826 & 30,527 & 6,732 & \\
\hline
\end{tabular}

Table 3: Total financial assets by type - median for those with any, by country of birth.

it includes median total financial assets only for those who own some assets. For Mainland Chinese immigrants, financial asset ownership increases directly with tenure in the U.S., that is, those with greater time in the U.S. had accumulated larger portfolios of financial assets. By contrast, for Hong Kong, Taiwanese, and Indian immigrants, those with more moderate levels of tenure (11-15 years) owned the largest amounts of financial assets. This is an important finding that reflects the types of people who were selected on in various waves of immigration; however, it also reflects the practice of younger immigrants bringing their parents to live with them, a practice that is common for Hong Kong, Taiwanese, and Indian immigrants. This Figure also emphasizes that the financial assets owned by Hong Kong, Taiwanese, and Indian immigrants with more than 10 years of tenure in the U.S. far exceeded the assets held by other immigrants.

Next, multivariate analyses (Ordinary Least Squares regression) using total financial assets (logged) as the dependent variable demonstrate the relative weight of race/nativity and other factors that are associated with financial asset ownership, The first model is a base model that includes only race and ethnicity; the a second model controls for tenure in the U.S. in order to ascertain that additional effect of this variable; the final model includes all race, tenure, age, education, and control variables. The omitted category is native blacks; this is the omitted category because native blacks have been shown to have consistently low asset ownership, making them a consistent albeit unfortunate group for comparison, found that the patterns that were evident in the descriptive statistics hold in the multivariate analyses. In particular, immigrants from Mainland China owned more financial assets than native blacks and other immigrants in all models and more than native whites once tenure in the U.S. was controlled. Immigrants from Hong Kong, Taiwan, and India owned more financial assets than native blacks, native whites, and other immigrants in all models. The change in the size of the race/nativity variables relative to other variables in the models in Models 2 and 3 suggest that tenure, age, and the other control variables explain some of the effect of race and nativity on financial asset ownership, consistent with the patterns that emerged in the descriptive statistics (above) (Table 4).

Finally, because stock ownership is an important component of total financial assets for understanding saving, risk taking, inequality, and the global flow of funds, the final multivariate analysis (Ordinary Least Squares regression) uses the total amount of stocks owned (logged) as the dependent variable (Table 5). The results show that the pattern of results for stock ownership is identical to that of total financial asset ownership (Table 4). That is, immigrants from Mainland China owned more stocks than native blacks and other immigrants in all models and more than native whites once tenure in the U.S. was controlled. Immigrants from Hong Kong, Taiwan, and India owned more stocks than native blacks, native whites, and other immigrants in all models.

\section{Conclusion}

This paper studied how Chinese and Indian immigrants to the United 
Citation: Keister LA (2015) Financial Asset Ownership:The Case of Chinese and Indian Immigrants to the United States. Bus Eco J 6: 184. doi:10.4172/2151-6219.1000184

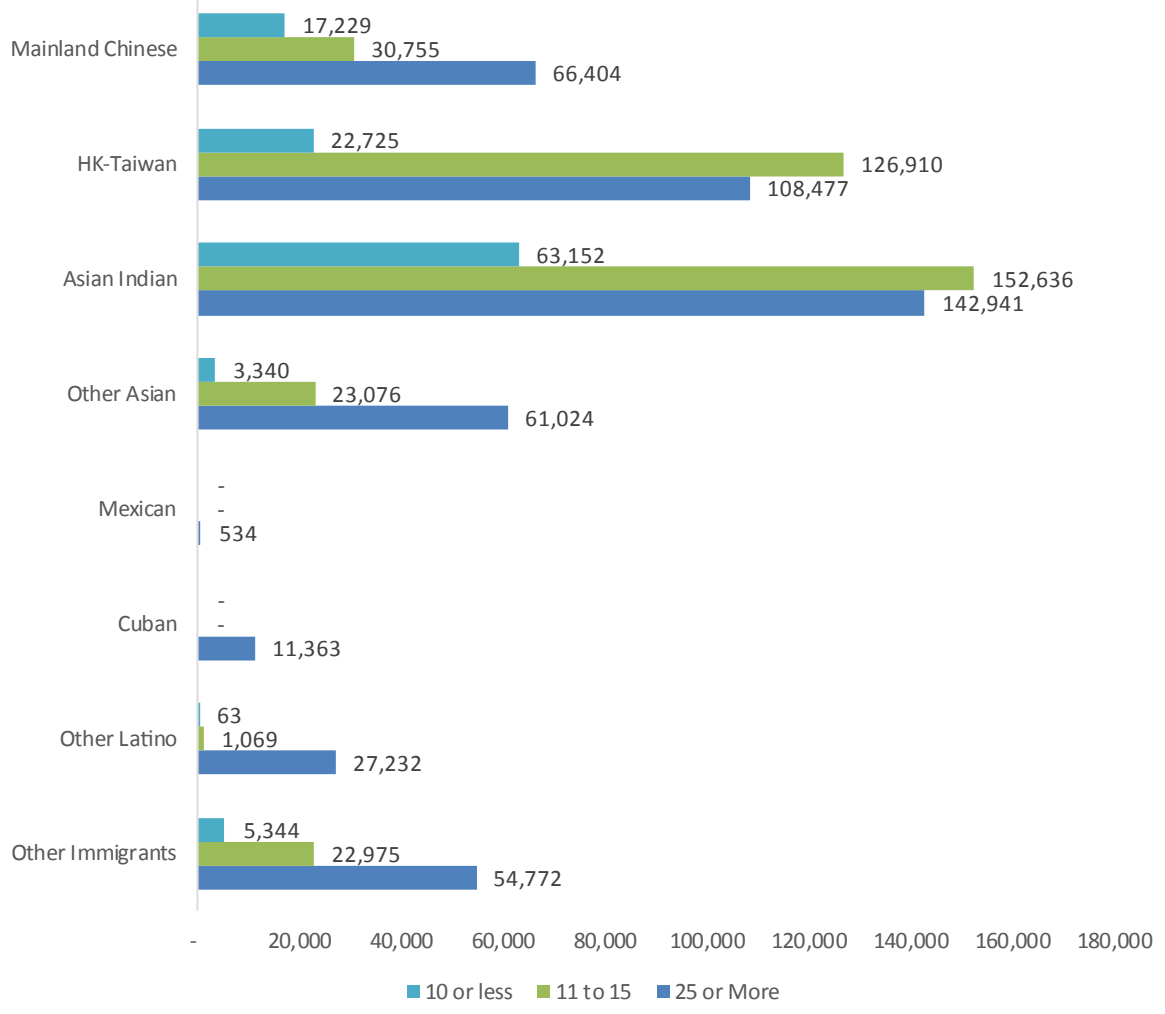

Figure 1: Immigrant median total financial assets by US tenure.

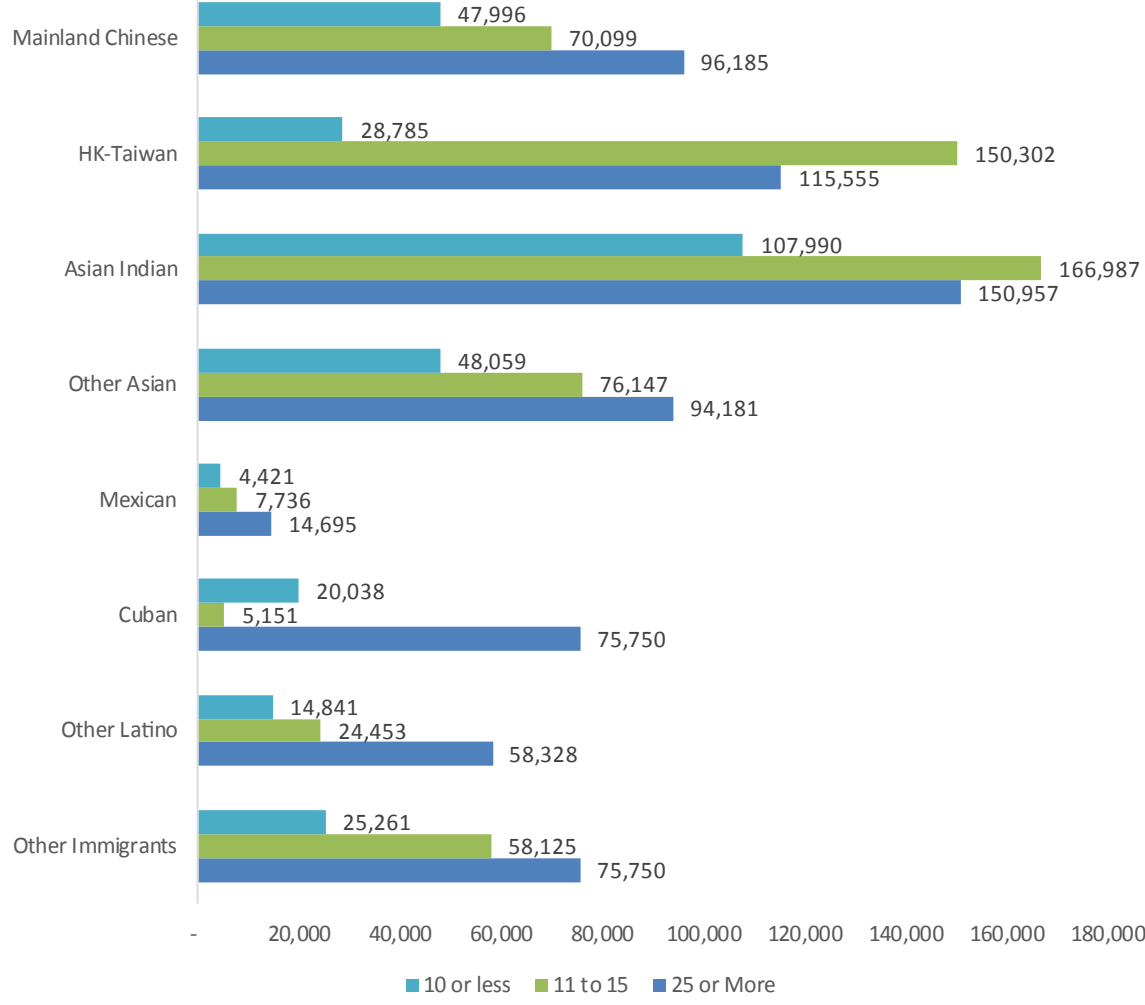

Figure 2: Immigrant median total financial assets by US tenure for those with any. 
Citation: Keister LA (2015) Financial Asset Ownership:The Case of Chinese and Indian Immigrants to the United States. Bus Eco J 6: 184. doi:10.4172/2151-6219.1000184

Page 6 of 9

\begin{tabular}{|c|c|c|c|}
\hline & Model 1 & Model 2 & Model 3 \\
\hline \multirow[t]{2}{*}{ Constant } & $10.11^{* * *}$ & $10.11^{* \star *}$ & $7.74^{\star * \star}$ \\
\hline & $(0.03)$ & $(0.03)$ & $(0.04)$ \\
\hline \multicolumn{4}{|l|}{ Race/Nativity ${ }^{1}$} \\
\hline \multirow[t]{2}{*}{ Mainland Chinese } & $0.43^{\star *}$ & $0.94^{* * *}$ & 0.30 \\
\hline & $(0.14)$ & $(0.17)$ & $(0.16)$ \\
\hline \multirow[t]{2}{*}{ HK-Taiwan } & $0.84^{* * *}$ & $1.30^{* * *}$ & $0.49^{*}$ \\
\hline & $(0.18)$ & $(0.21)$ & $(0.19)$ \\
\hline \multirow[t]{2}{*}{ Asian Indian } & $1.34^{* * *}$ & $1.80^{* * *}$ & $0.53^{* * *}$ \\
\hline & $(0.13)$ & $(0.17)$ & $(0.15)$ \\
\hline \multirow[t]{2}{*}{ Other Asian } & $0.55^{\star * *}$ & $0.87^{* * *}$ & 0.16 \\
\hline & $(0.07)$ & $(0.12)$ & $(0.11)$ \\
\hline \multirow[t]{2}{*}{ Native Asian } & $0.17^{*}$ & $0.17^{*}$ & -0.05 \\
\hline & $(0.08)$ & $(0.08)$ & $(0.07)$ \\
\hline \multirow[t]{2}{*}{ Mexican } & $-1.14^{* * *}$ & $-0.91^{* * *}$ & $-0.61^{* * *}$ \\
\hline & $(0.07)$ & $(0.12)$ & $(0.11)$ \\
\hline \multirow[t]{2}{*}{ Cuban } & -0.10 & 0.12 & -0.29 \\
\hline & $(0.15)$ & $(0.19)$ & $(0.17)$ \\
\hline \multirow[t]{2}{*}{ Other Latino } & -0.10 & 0.19 & -0.13 \\
\hline & $(0.07)$ & $(0.12)$ & $(0.11)$ \\
\hline \multirow[t]{2}{*}{ Native Latino } & $-0.12^{*}$ & -0.09 & $-0.18^{\star \star \star}$ \\
\hline & $(0.05)$ & $(0.05)$ & $(0.05)$ \\
\hline \multirow[t]{2}{*}{ Native White } & $0.80^{* * *}$ & $0.80^{* \star *}$ & $0.34^{* \star *}$ \\
\hline & $(0.03)$ & $(0.03)$ & $(0.03)$ \\
\hline \multirow[t]{2}{*}{ Other Immigrant } & $0.39^{* * *}$ & $0.59^{* * *}$ & 0.01 \\
\hline & $(0.06)$ & $(0.11)$ & $(0.10)$ \\
\hline \multirow[t]{2}{*}{ Missing Ethnicity } & $0.21^{* * *}$ & $0.2^{* * *}$ & -0.01 \\
\hline & $(0.04)$ & $(0.04)$ & $(0.04)$ \\
\hline \multicolumn{4}{|l|}{ Tenure in US ${ }^{2}$} \\
\hline \multirow[t]{2}{*}{0 to $10 \mathrm{yrs}$} & & $-0.81^{* * *}$ & $-0.69^{* \star *}$ \\
\hline & & $(0.11)$ & $(0.10)$ \\
\hline \multirow[t]{2}{*}{10 to $25 \mathrm{yrs}$} & & $-0.43^{* * *}$ & $-0.36^{\star \star *}$ \\
\hline & & $(0.11)$ & $(0.10)$ \\
\hline \multirow[t]{2}{*}{$25+y r s$} & & 0.09 & 0.14 \\
\hline & & $(0.10)$ & $(0.09)$ \\
\hline \multicolumn{4}{|l|}{$\mathrm{Age}^{3}$} \\
\hline \multirow[t]{2}{*}{40 to 54 yrs } & & & $0.44^{\star * *}$ \\
\hline & & & $(0.02)$ \\
\hline $55+y r s$ & & & $0.75^{\star \star *}$ \\
\hline & & & $(0.02)$ \\
\hline & & & \\
\hline & & & \\
\hline & & & \\
\hline (continued) & & & \\
\hline & Model 1 & Model 2 & Model 3 \\
\hline Education $^{4}$ & & & \\
\hline HS Graduate & & & $0.86^{\star \star *}$ \\
\hline & & & $(0.03)$ \\
\hline Some College & & & $1.18^{\star * *}$ \\
\hline & & & $(0.03)$ \\
\hline College & & & $1.55^{\star \star *}$ \\
\hline & & & $(0.03)$ \\
\hline Advanced Degree & & & $1.98^{\star \star *}$ \\
\hline & & & $(0.03)$ \\
\hline
\end{tabular}


Citation: Keister LA (2015) Financial Asset Ownership:The Case of Chinese and Indian Immigrants to the United States. Bus Eco J 6: 184. doi:10.4172/2151-6219.1000184

Page 7 of 9

\begin{tabular}{|c|c|}
\hline \multicolumn{2}{|l|}{ Income } \\
\hline \multirow[t]{2}{*}{ Annual } & $0.01^{* \star *}$ \\
\hline & $(0.00)$ \\
\hline \multicolumn{2}{|l|}{ Family } \\
\hline \multirow[t]{2}{*}{ Female Head } & $-0.31^{* * *}$ \\
\hline & $(0.02)$ \\
\hline \multirow[t]{2}{*}{ Children } & -0.01 \\
\hline & $(0.01)$ \\
\hline \multirow[t]{2}{*}{ Married } & $0.52^{\star \star \star}$ \\
\hline & $(0.02)$ \\
\hline \multicolumn{2}{|l|}{ Year $^{5}$} \\
\hline \multirow[t]{2}{*}{ year 1996} & $0.75^{\star \star \star}$ \\
\hline & $(0.02)$ \\
\hline \multirow[t]{2}{*}{ year 2001} & $0.69^{* * *}$ \\
\hline & $(0.02)$ \\
\hline \multicolumn{2}{|l|}{ Region $^{6}$} \\
\hline \multirow[t]{2}{*}{ Midwest } & $0.15^{\star * *}$ \\
\hline & $(0.02)$ \\
\hline \multirow[t]{2}{*}{ Northeast } & $0.07^{\star \star}$ \\
\hline & $(0.02)$ \\
\hline \multirow[t]{2}{*}{ South } & $0.16^{* \star *}$ \\
\hline & $(0.02)$ \\
\hline \multirow[t]{2}{*}{ Other } & -0.12 \\
\hline & $(0.09)$ \\
\hline $\begin{array}{l}\text { Notes: } \\
\text { Standard errors in parentheses } \\
{ }^{*} p<0.05{ }^{* *} p<0.01{ }^{* * *} p<0.001 \\
\text { 1. Reference race/nativity is native blacks } \\
\text { 2. Reference tenure is whole life }\end{array}$ & $\begin{array}{l}\text { omitted } \\
\text { school }\end{array}$ \\
\hline
\end{tabular}

Table 4: Regression models of total financial assets (logged) for those with any.

\begin{tabular}{|c|c|c|c|}
\hline & Model 1 & Model 2 & Model 3 \\
\hline \multirow[t]{2}{*}{ Constant } & $9.18^{* * *}$ & $9.18^{\star * *}$ & $7.30^{* * *}$ \\
\hline & $(0.08)$ & $(0.08)$ & $(0.13)$ \\
\hline \multicolumn{4}{|l|}{ Race/Nativity ${ }^{1}$} \\
\hline \multirow[t]{2}{*}{ Mainland Chinese } & $0.90^{\star * *}$ & $0.99^{* *}$ & 0.33 \\
\hline & $(0.26)$ & $(0.37)$ & $(0.35)$ \\
\hline \multirow[t]{2}{*}{ HK-Taiwan } & $0.64^{*}$ & 0.68 & 0.23 \\
\hline & $(0.31)$ & -0.40 & $(0.38)$ \\
\hline \multirow[t]{2}{*}{ Asian Indian } & $1.00^{* * *}$ & $1.16^{* * *}$ & 0.41 \\
\hline & $(0.22)$ & $(0.34)$ & $(0.32)$ \\
\hline \multirow[t]{2}{*}{ Other Asian } & $0.64^{\star \star \star}$ & $0.61^{*}$ & 0.25 \\
\hline & $(0.15)$ & $(0.29)$ & $(0.28)$ \\
\hline \multirow[t]{2}{*}{ Native Asian } & $1.03^{* \star *}$ & $1.03^{* * *}$ & $0.74^{* * *}$ \\
\hline & $(0.19)$ & $(0.19)$ & $(0.18)$ \\
\hline \multirow[t]{2}{*}{ Mexican } & 0.11 & 0.10 & 0.01 \\
\hline & $(0.3)$ & $(0.41)$ & $(0.38)$ \\
\hline \multirow[t]{2}{*}{ Cuban } & $1.01^{*}$ & $1.01^{*}$ & 0.55 \\
\hline & $(0.4)$ & $(0.49)$ & $(0.46)$ \\
\hline \multirow[t]{2}{*}{ Other Latino } & $0.68^{* * *}$ & $0.73^{*}$ & 0.23 \\
\hline & $(0.17)$ & $(0.30)$ & $(0.28)$ \\
\hline \multirow[t]{2}{*}{ Native Latino } & $0.60^{* * *}$ & $0.59^{* * *}$ & $0.62^{* * *}$ \\
\hline & $(0.14)$ & $(0.14)$ & $(0.13)$ \\
\hline \multirow[t]{2}{*}{ Native White } & $1.00^{\star * *}$ & $1.00^{* * *}$ & $0.68^{* * *}$ \\
\hline & $(0.08)$ & $(0.08)$ & $(0.08)$ \\
\hline \multirow[t]{2}{*}{ Other Immigrant } & $1.14^{\star * *}$ & $1.08^{* * *}$ & $0.56^{*}$ \\
\hline & $(0.13)$ & $(0.28)$ & $(0.26)$ \\
\hline
\end{tabular}


Citation: Keister LA (2015) Financial Asset Ownership:The Case of Chinese and Indian Immigrants to the United States. Bus Eco J 6: 184. doi:10.4172/2151-6219.1000184

Page 8 of 9

\begin{tabular}{|c|c|c|c|}
\hline \multirow[t]{2}{*}{ Missing Ethnicity } & $0.68^{* * *}$ & $0.68^{\star \star \star}$ & $0.63^{* * *}$ \\
\hline & $(0.11)$ & $(0.11)$ & $(0.10)$ \\
\hline \multicolumn{4}{|l|}{ Tenure in US ${ }^{2}$} \\
\hline \multirow[t]{2}{*}{0 to $10 \mathrm{yrs}$} & & -0.37 & 0.24 \\
\hline & & $(0.30)$ & $(0.28)$ \\
\hline \multirow[t]{2}{*}{10 to $25 \mathrm{yrs}$} & & -0.11 & 0.30 \\
\hline & & $(0.28)$ & $(0.26)$ \\
\hline \multirow[t]{2}{*}{$25+y r s$} & & 0.20 & 0.18 \\
\hline & & $(0.26)$ & $(0.24)$ \\
\hline \multicolumn{4}{|l|}{$\mathrm{Age}^{3}$} \\
\hline \multirow[t]{2}{*}{40 to $54 \mathrm{yrs}$} & & & $0.69^{* \star *}$ \\
\hline & & & $(0.04)$ \\
\hline \multirow[t]{3}{*}{$55+y r s$} & & & $1.72^{* * *}$ \\
\hline & & & $(0.04)$ \\
\hline & Model 1 & Model 2 & Model 3 \\
\hline \multicolumn{4}{|l|}{ Education $^{4}$} \\
\hline \multirow[t]{2}{*}{ HS Graduate } & & & $0.45^{* * *}$ \\
\hline & & & $(0.08)$ \\
\hline \multirow[t]{2}{*}{ Some College } & & & $0.55^{\star \star *}$ \\
\hline & & & $(0.08)$ \\
\hline \multirow[t]{2}{*}{ College } & & & $0.83^{* * *}$ \\
\hline & & & $(0.08)$ \\
\hline \multirow[t]{2}{*}{ Advanced Degree } & & & $1.17^{\star \star *}$ \\
\hline & & & $(0.08)$ \\
\hline \multicolumn{4}{|l|}{ Income } \\
\hline \multirow[t]{2}{*}{ Annual } & & & $0.00^{\star * *}$ \\
\hline & & & $(0.00)$ \\
\hline \multicolumn{4}{|l|}{ Family } \\
\hline \multirow[t]{2}{*}{ Female Head } & & & $-0.28^{\star * *}$ \\
\hline & & & $(0.06)$ \\
\hline \multirow[t]{2}{*}{ Children } & & & $-0.03^{*}$ \\
\hline & & & $(0.02)$ \\
\hline \multirow[t]{2}{*}{ Married } & & & $0.39^{* \star *}$ \\
\hline & & & $(0.05)$ \\
\hline \multicolumn{4}{|l|}{ Year $^{5}$} \\
\hline \multirow[t]{2}{*}{ year 1996} & & & $0.33^{* * *}$ \\
\hline & & & $(0.04)$ \\
\hline \multirow[t]{2}{*}{ year 2001} & & & $0.16^{* * *}$ \\
\hline & & & $(0.04)$ \\
\hline \multicolumn{4}{|l|}{ Region $^{6}$} \\
\hline Midwest & & & $-0.11^{*}$ \\
\hline & & & $(0.04)$ \\
\hline Northeast & & & -0.06 \\
\hline & & & $(0.04)$ \\
\hline South & & & $-0.09^{*}$ \\
\hline & & & $(0.04)$ \\
\hline Other & & & -0.17 \\
\hline & & & $(0.15)$ \\
\hline $\begin{array}{r}\text { Stand } \\
{ }^{*} p<0.0 \\
\text { 1. Referenc } \\
\text { 2. Refe }\end{array}$ & $\begin{array}{l}\text { leses } \\
.001 \\
\text { tive blacks } \\
\text { le life }\end{array}$ & & $\begin{array}{l}25 \text { omitted } \\
\text { igh school }\end{array}$ \\
\hline
\end{tabular}

Table 5: Ordinary least squares regression models of total stocks (logged) for those with any. 
Citation: Keister LA (2015) Financial Asset Ownership:The Case of Chinese and Indian Immigrants to the United States. Bus Eco J 6: 184. doi:10.4172/2151-6219.1000184

States own financial assets; it compared their asset ownership to that of native whites and blacks and to other immigrants and investigated the ownership of total financial assets and various types of financial assets including stocks and mutual funds, interest-earning bank accounts, Individual Retirement and Keogh accounts, and whole life insurance, It focused on Chinese and Indian immigrants to the U.S. because these are two large and growing groups whose financial asset ownership is potentially unique in instructive ways, The analyses are based on data from the United States Census Bureau's Survey of Income and Program Participation (SIPP) that the paper shows that these groups were highly likely to own all types of financial assets and to hold large values in their accounts, even though previous research pays little attention to their wealth ownership. My descriptive statistics showed that each of these groups hold rather large balances in their financial accounts, and my multivariate models showed that immigrants from Mainland China owned more total financial and more stocks than native blacks and other immigrants in all models and more than native whites once tenure in the U.S. was controlled. My multivariate models also showed that immigrants from Hong Kong, Taiwan, and India owned more total financial assets and more stocks than native blacks, native whites, and other immigrants in all models. These findings are relevant across a large number of academic disciplines and fields. Indeed, understanding who owns financial assets has implications for understanding financial planning, risk taking, and saving. Given the degree to which financial markets in the U.S. influence financial markets and financial well-being globally, these patterns also have implications for understanding wellbeing and inequality across the globe. Future research might usefully focus on how these patterns vary for membership of upper income and wealth groups (e.g., the one percent) given that most financial assets tend to be owned at the top of the income and wealth distributions. Future research might also explore how ethnicity is associated with membership in the one percent, a question that has not been explored previously but that will also continue to grow in importance as the wealth of Chinese and Indian immigrants to the U.S. grows.

\section{Acknowledgement}

I acknowledged a grant from the National Science Foundation (SES-1322738) that supported this research. Brian Aronson assisted with analyses

\section{References}

1. Bajtelsmit, Vickie L, VanDerhei JL (1997) "Risk Aversion and Pension
Investment Choices." in Positioning Pensions for the Twenty-First Century In: Gordon MS, Mitchell OS, Marc M. Twinney MM (Eds.). PA: University of Pennsylvania Press, Philadelphia.

2. Guseva A, Rona-Ta A (2001) "Uncertainty, Risk, and Trust: Russian and American Credit Card Markets Compared." American Socioligical Review 66: 623-646.

3. Fry R, Paul T (2013) An Uneven Recovery, 2009-2011: A Rise in Wealth for the Wealthy; Declines for the Lower 93\%. Pew Research Center, Washington: DC

4. Edward NW (2010) "Recent Trends in Household Wealth, 1983-2009: The Irresistible Rise of Household Debt." Review of Economcs and Institutions 2 53-88.

5. Shen CH, Lee CC (2006) "Same Financial Development Yet Different Economic Growth-Why? Journal of Money, Credit and Banking 38:1907-1944.

6. Lee CC (2005) "Banking Development, Stock Market Development, and Economic Growth: The Case of Taiwan, Taiwan Economic Forecast and Policy 35: 79-105.

7. Mizruchi, Mark S, Stearns LB (1994) "Money, Banking, and Financial Markets." in The Handbook of Economic Sociology, In: Smelser NJ, Swedberg R (Eds.) Princeton, NJ: Princeton University Press.

8. Pew Research Center (2012) "The Rise of Asian Americans." In: Pew Research Center. Social \& Demographic Trends.

9. Nathan WP, Trevelyan EN (2011) "The Newly Arrived Foreign-Born Population of the United States: 2010". American Community Survey Briefs. Washington DC: U.S. Census Bureau.

10. Wadwa V, Saxenian A, Rissing B, Gereffi G (2007) "America's New Immigrant Entrepreneurs." Kansas City, MO: Kauffman Foundation.

11. Lingxin H (2007) Color Lines, Country Lines: Race, Immigration, and Wealth Stratification in America. New York: Russell Sage Foundation, New York.

12. Richard A, Nee V (2003) Remaking the American Mainstream: Assimilation and Contemporary Immigration. Cambridge, MA: Harvard University Press.

13. William H, Portes A, Lynch SM (2011) "Dreams Fulfilled, Dreams Shattered Determinants of Segmented Assimilation in the Second Generation." Social Forces 89: 733-762.

14. Franco M (1992) "Life Cycle, Individual Thrift, and the Wealth of Nations." In: Maler KG (Ed.). Nobel Lectures: Economic Sciences, 1981-1990. New Jersey: World Scientific, New Jersey.

15. Cynthia F (2005) "Does Selective Migration Matter? Explaining Ethnic Disparities in Educational Attainment among Immigrants' Children." International Migration Review 39: 841-871.

16. Lisa AK (2014) "The One Percent." The Annual Review of Sociology 40: 347-367.

OMICS International: Publication Benefits \& Features

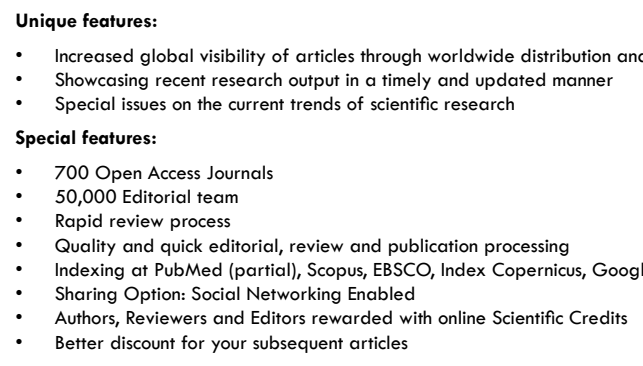

Keister LA (2015) Financial Asset Ownership:The Case of Chinese and Indian Immigrants to the United States. Bus Eco J 6: 184. doi:10.4172/2151 6219.1000184
- Better discount for your subsequent articles

Submit your manuscript at: http://www.omicsgroup.org/iournals/submission 